\title{
ANALYSIS OF THE EFFECTS OF RAINFALL, LAND USE CHANGES, AND AMOUNT OF WATER USAGE ON GROUNDWATER LEVEL DECREASING (STUDY IN GEDEBAGE)
}

\author{
Muhammad Hafidh Alhaq ${ }^{1}$, Bakhtiar Abu Bakar ${ }^{2}$, Didin Kusdian ${ }^{3}$ \\ ${ }^{1}$ Universitas Sangga Buana YPKP, Bandung \\ ${ }^{2}$ Dosen Universitas Sangga Buana YPKP, Bandung \\ ${ }^{3}$ Dosen Universitas Sangga Buana YPKP, Bandung
}

Email : hafidh.alhaq@gmail.com (Universitas Sangga Buana YPKP)

\begin{abstract}
ABSTRAK
Sustainable urban development has been one of the main concerns for policy-makers. Increasing rate of population and urbanization have resulted in several socio-environmental impacts on people. Hence, water resources management in cities, as one of the most vital strategies, has become more complicated and challenging. In this study, the impact of precipitation, land-use changes, and amount of groundwater usageon groundwater level fluctuations was assessed. Using precipitation, remote sensing maps data from satellites, data of groundwater level, and land-use was extracted and processed by different formula and mapping tools. Gedebage Area in Bandung, Indonesia was selected as the case study location. The potential impacts of urban development in this city on groundwater resources were studied. The results suggest that from 2014 to 2018, Groundwater level decreasion was to increase simultaneously with run off discharge. Society perception confirmed that $95 \%$ is affected by precipitation, landuse change and amount of water usage at significance $<0.05$ while this change rate was more intense during previous decades and is predicted to be increased by 2030. Since relationship between precipitation, land-use change and amount of groundwater usage on groundwater level decreasion is undeniable, novel methodology of this stsudy can be employed for other fastgrowing cities in Indonesia.
\end{abstract}

\section{INTRODUCTION}

According to regulation No. SDA 7 of 2004, water resources management is an effort to plan, fulfill, monitor, and evaluate the implementation of water resources conservation, water resources utilization, and water damage control. There are two main components of water resources, surface water and groundwater. Surface water and river area management are the basic concepts that contain one or more watersheds. Integrated water resources management includes management of surface water and ground water. Essentially there is a relationship between surface water and groundwater, namely the occurrence of groundwater supply in surface water, and surface water can also supply groundwater under certain conditions [1].

Water is an important natural resources has unique characteristics compared to other resources. Water is a renewable and dynamic resource. This means that the main source of water in the form of rain always come in accordance with the time or season throughout the year. However, in 
certain conditions water can be nonrenewable, for example in certain geological conditions where the process of ground water travel takes thousands of years, so that when excessive groundwater is extracted, water will run out. Therefore, it is not an exaggeration to say by Pindar "Woter is the best of all things." Life is a gift from God, the existence of life is due to the presence of water. Maintaining the existence of water in a sustainable manner, we also maintain life, which means also maintain God's grace [2]. Kodoatie, 2012 stated the process of ground water formation is caused by the process of water infiltration on the ground surface that enters the unsaturated zone. The percolation automatically occurred when the water content in the unsaturated zone reaches the field capacity because of gravity that lead to the saturated zone.To take ground water with a large enough amount, for example in industry, the most used method is to make deep wells which are generally made of pipes to exploit deep ground water [3]. Regional spatial planning is to improve and develop socio-economic activities. In general, spatial planning prioritizes spatial and economic values, while environmental values are ignored [4].

\section{MATERIALS AND METHOD}

\section{Study Area}

The study is located in Gedebage District, Bandung City, Indonesia. The Gedebage District is designated as a Gedebage City Sub-Region based on the 2011-2031 Bandung City Spatial Plan. It has a total area of $9.80 \mathrm{~km}^{2}$. Gedebage is a floodplain area due to the low terrain, which has an average land surface elevation of $665 \mathrm{~m}$ above sea level. Other areas in the Bandung City has an average elevation of $700 \mathrm{~m}$ above sea level which caused water flow to the river is slow in Gedebage Area, hence being prone to flooding.

Gedebage District was selected for hydrological, land-use change, and decreasing groundwater level modeling. Precipitation continues to increase from year to year. One of the factors is the global climate change phenomenon. The development is also increased in line with government policies regarding the Gedebage Primary Center, where there are a variety of important facilities on a large scale such as container terminals, wholesale markets, industries, trade centers, new settlements, and sports centers. This phenomenon causes changes in land use and increased demand for clean water. 


\section{Data Description}

Data sources are divided into two, namely primary data and secondary data. Primary data is obtained by questionnaire. The sample size approach in most ex post facto studies and experimental samples totaling 30 or more is highly recommended [5]. Whereas secondary data is obtained from the records and documentation of the government agency. Obtained secondary data is in the form of precipitation, landuse change, and groundwater level data. Precipitation data is obtained from two stations around the Gedebage District, Cibiru and Gedebage rain posts. Landuse change data is obtained from the digitized maps. Groundwater level data was obtained from The Energy and Mineral Resources Agency of West Java.

\section{Data Analysis}

Precipitation characteristics include intensity, duration, depth, and frequency. Intensity related to duration and frequency can be expressed with Intensity Duration Frequency (IDF) curves. IDF curves are obtained by finding suitable distribution types from precipitation data. The annual maximum daily precipitation data for 10 years of observation was used to find the pattern of rainfall distribution through statistical parameters of the probability of rainfall distribution using the Gumbel, normal, normal log, and Pearson log type 3 methods [7]. The study of land use change was carried out using remote sensing methods and geographic information systems. The identification of land use change maps is carried out using the 20142018 land use map overlapping process (the results of digitization) with UTM (Universal Transverse Mercator) coordinates. Image contrast improvement through histogram alignment is done by supervised classification techniques which are divided into 4 (seven) classes, namely rice fields, settlements, vegetation, and ordinary land [6].

Run-off is the part of rainfall that flows above the land surface towards a larger body of water. Run-off is a small portion of rainfall that moves above the surface or through land to surface water features (ponds, lakes, rivers, rivers, etc.). Estimation of peak run-off is very important for designing soil conservation structures with adequate capacity. Peak run-off can be estimated using the Rational method, where total run-off is calculated using the Curve Number Method. The Rational Method is the most method 
widely used for estimating peak run-off which is quite accurate [8].

The rational method [9] is the most common method for estimating peak runoff in small watersheds (less than 1,300 ha). This method is based on the assumption that (i) rainfall occurs at a uniform intensity for a certain duration at least the same time as the watershed concentration, and (ii) rainfall occurs at a uniform intensity throughout the watershed area. Run-off discharge (Qp) can be calculated using the formula:

$$
\mathrm{Qp}=0.0278 \mathrm{CIA}
$$

Where $\mathrm{Q}=$ peak runoff velocity $(\mathrm{m} 3 / \mathrm{s}), \mathrm{C}$ $=$ runoff coefficient, $\mathrm{I}=$ rainfall intensity for the same duration as the concentration time, $(\mathrm{cm} /$ hour$)$, and $\mathrm{A}=$ watershed area (ha).

Land-use changes maps are used to calculate the amount of run-off over the last 5 years. groundwater level water changes was analyzed by inputting UTM coordinate data from monitoring well which hava locations and groundwater level elevation data. XYZ tabular data was inputted on a three-dimensional grid which was the basis for forming threedimensional contours and surfaces.
Inferential statistics produce analytical results which are presented by frequency distribution tables, line graphs, bar graphs, piecharts, and pictograms. Discussion is an in-depth explanation and interpretation of the data that has been presented [22]. The steps taken are testing the normality of the data, determining significance, and regression analysis. To draw conclusions the significance level of $5 \%(\alpha=0.05)$ is used, meaning that if the null hypothesis is rejected (accepted) with a 95\% confidence level, then it is likely that the results of drawing conclusions have a truth of $95 \%$ and this indicates the presence/ absence convincing influence (significant) between these two variables. The significance results are used to clarify the results of mathematical calculations how much the influence of rainfall, land use changes, and amount of groundwater usage affect the groundwater levels.

\section{RESULTS AND DISCUSSION}

\section{Intensity Duration Frequency Analysis}

The type of distribution that meets the requirements was Log Pearson Type III. We used the compatibility test of the distribution with 2 methods. To test the suitability of a distribution distribution used the Chi Square Test [6]. From the 
Chi-Square test, the Chi-Square Count was 12.18, while the Chi-Square Table (critical) is 13.28 with $1 \%$ alpha. Because ChiSquare count <Chi-Square table (12.18 <13.28) then the data can be received. Whereas with Smirnov-Kolmogorov. The calculation results show the valueof Dmax $=0.286$. while the value of $\mathrm{D}$ table at the amount of data $n=11$ is 0.39122 at the significance of alpha 5\%. Because the calculated $\mathrm{D}$ value is smaller than the $\mathrm{D}$ table $(0.286<0.39122)$, the distribution equation obtained can be accepted. Intensity Duration Frequency Curve is shown in Fig 1.

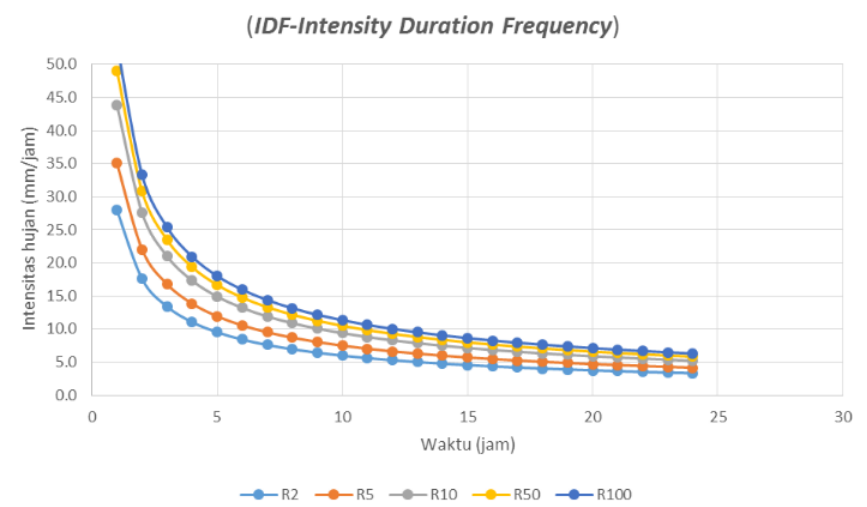

Fig 1. Curves of intensity, duration, and frequency of precipitation

\section{Land-use Changes Analysis}

Land-use change was analyzed by the GIS (Geographic Information System) method digitized on the last 5 years maps. Taking picture process used the historical method on google earth after streaming 100\% image data which will be digitized. Image georeferencing was obtained by UTM coordinates methods. Digitization results displayed different color codes that indicate differences in land-use Fig. 1, Fig. 2, Fig. 3, Fig. 4, Fig. 5. the digitization area for different colors is recapitulated in the table then becomes the data to calculate the surface peak runoff. 
ISSN 1979-4835

E-ISSN 2721-2335

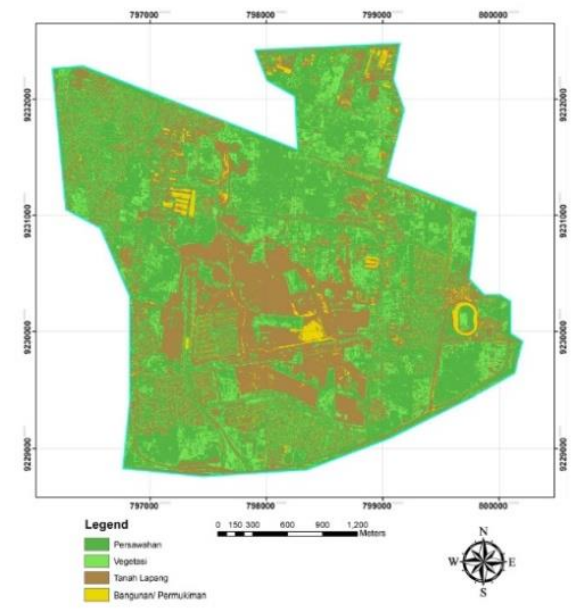

Fig 2. Land-Use in Gedebage Area in 2014

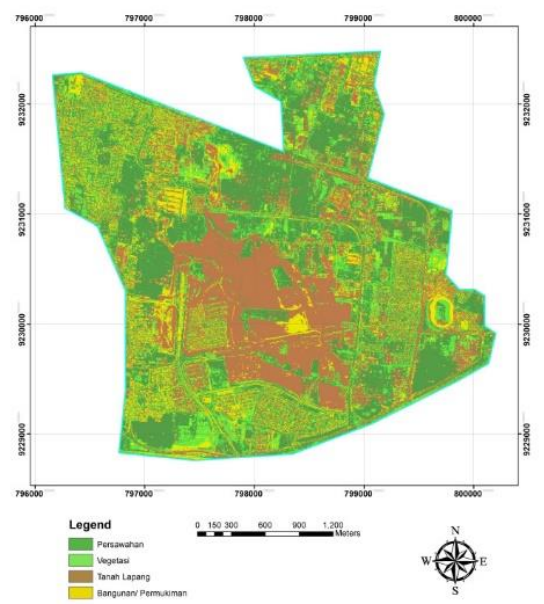

Fig 3. Land-Use in Gedebage Area in 2015

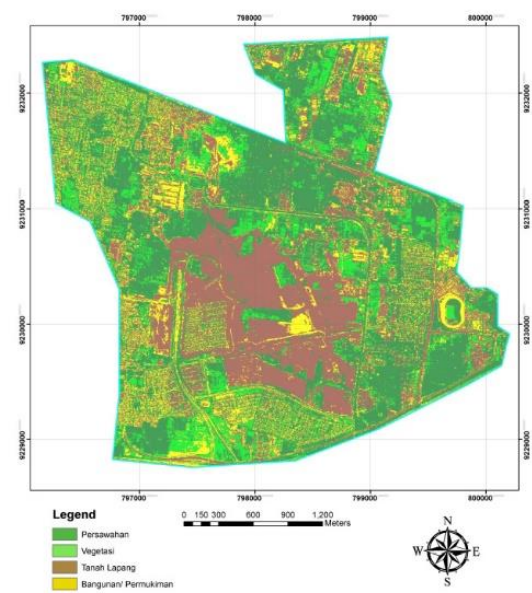

Fig 4. Land-Use in Gedebage Area in 2016 


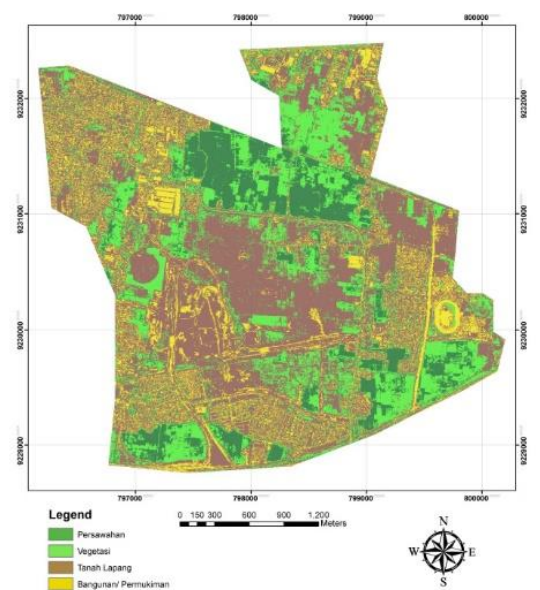

Fig 5. Land-Use in Gedebage Area in 2017

Table 1 Area Value of Changes in Land-Use for 2014-2018

\begin{tabular}{lccccc}
\hline & \multicolumn{5}{c}{ Years } \\
\cline { 2 - 6 } Land-Use & \multicolumn{5}{c}{$(\mathrm{Ha})$} \\
\cline { 2 - 6 } & 2018 & 2017 & 2016 & 2015 & 2014 \\
\hline Soil Ground & 278.54 & 345.91 & 317.54 & 323.88 & 209.84 \\
Vegetation & 137.01 & 167.19 & 159.74 & 199.45 & 167.17 \\
Field & 301.79 & 335.22 & 375.26 & 338.58 & 498.97 \\
Building & 273.33 & 142.49 & 138.26 & 128.91 & 114.66
\end{tabular}

\section{Run-Off Analysis}

Naturally some of the rainwater that falls to the ground surface will seep into the ground and the rest will flow into surface runoff. The condition of the area where the rain falls will greatly affect the part of the rain that will seep into the ground and will form surface runoff. Regional characteristics affecting the part of rainwater include topography, soil type, and land use or land cover. This means that the characteristics of the physical environment have an influence on the hydrological response. 
The results showed an increment in runoff discharge over the five years from 20142018 using rational method. During this period an increase in runoff discharge by an average of $4 \%$ per year.

Table 2 The amount of runoff discharge for the 2014-2018 period.

\begin{tabular}{cc}
\hline Year & Runoff Discharge $(\mathrm{m} 3 / \mathrm{s})$ \\
\hline 2014 & 35.69 \\
2015 & 37.47 \\
2016 & 37.91 \\
2017 & 37.10 \\
2018 & 43.29 \\
\hline
\end{tabular}

The impact of surface runoff due to Groundwater volume and decreassion changes in land use increases then at the same time will reduce water infiltration to the ground. Factors affecting run-off discharge are infiltration, the amount of water retained by vegetation and a basin that results in inundation. If the run-off is large then the infiltration is small, while the run-off is low then the infiltration is high. This low run off causes the rainwater not to enter the ground so that it affects the groundwater level.

\section{analysis.}

Topographic map is a map that has information about the surface height at a place that is drawn with contour lines. The topographic information contained on a topographic map can be used to create a three-dimensional model of a surface. With the three-dimensional model the objects on the map are seen as more alive as they really are in nature, so to analyze a topographic map can be more easily done. To calculate the volume of groundwater reduction, a 3-dimensional model of groundwater contour was required. 


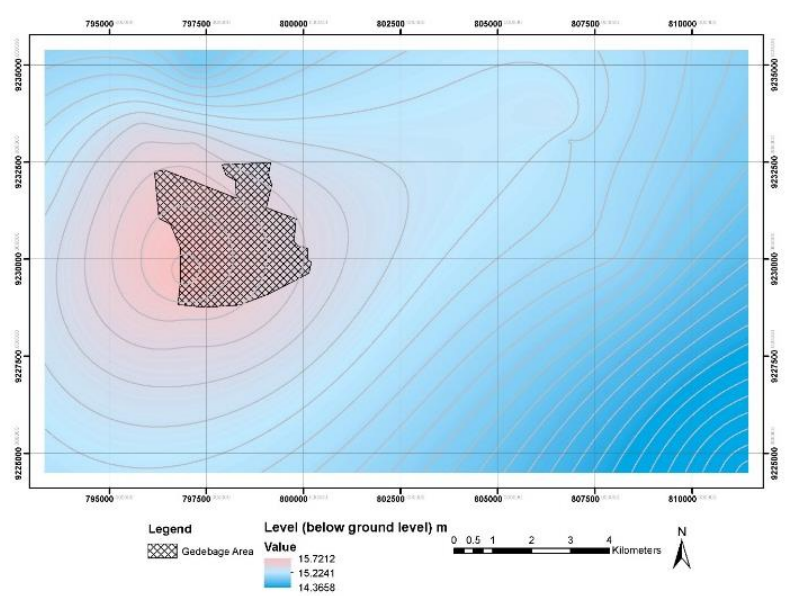

Fig 7. Gedebage Groundwater level in 2014

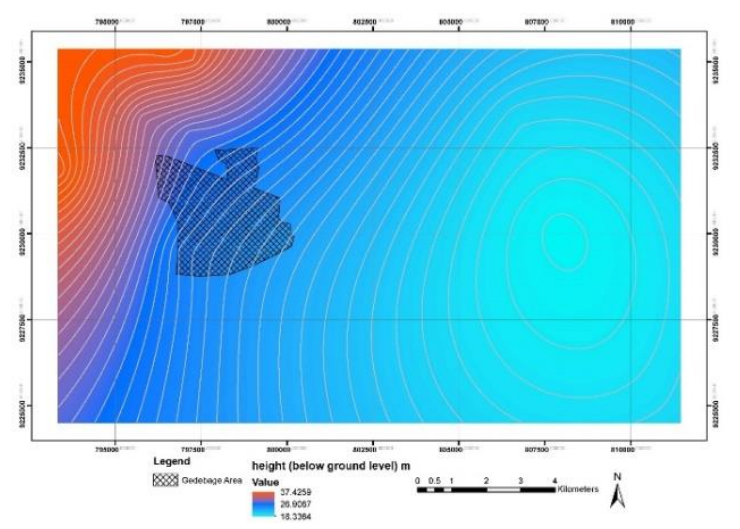

Fig 8. Gedebage Groundwater level in 2018

Effects of rainfall, changes in land use and amount of groundwater usage on the decreassion in groundwater level.

A model of the level of groundwater reduction developed through multiple linear regression which estimates the reduction in groundwater obtained from rainfall, changes in land cover, and the amount of groundwater use for the purpose of efficient management of groundwater resources in Gedebage Area, Bandung,
Indonesia . Through the application of the linear regression model, estimation of runoff from rainfall and estimation of water level parameters (Ground Water Depth) obtained from monitoring well monitoring are revised to produce a decrease model. The amount of influence analyzed from the model based on the estimated parameters of the predictor model (rainfall, change in land cover, amount of water use) evaluated gives a coefficient of determination (R2) 
0.947. The results obtained confirm the reliability and accuracy of the proposed model in the estimation of the rate of decline and predictions in the area. The application of multiple linear regression models provides an estimate of $23 \%$ / year for the rate of decline in groundwater.

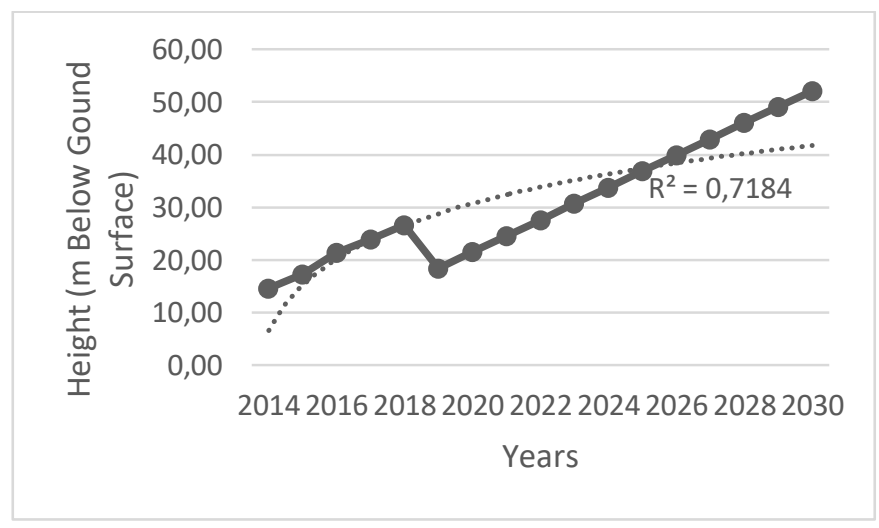

Fig 9. Goundwater Level Trend with Multiple Regression Prediction

Regression models to predict decreassion groundwater level through 2030 have been created based on these results Fig. 10. This regression model can serve as a scientific basis for the management and exploration of groundwater resources in the Gedebage Area. This approachment provided a new method for determining the level of groundwater decreassion due to runoff. This technique was expected to be able to provide alternatives as a prediction method for decreasing ground water level in certain area.

\section{Community Perceptions of}

Groundwater Level Decreassion in GedebageArea Analysis.
The study model used inferential methods by drawing conclusions based on fewer sample data into more general conclusions for a population. Inferential research is needed in this study so that to be more efficient research is carried out by taking a smaller number of samples from the existing population. In this inferential research, a prediction is made. Inferential statistics require the fulfillment of assumptions. The earliest assumption that must be met is that the sample is taken randomly from the population. This is necessary because inferential statistics there needs to be a sample from the population. Other assumptions that need to be met follow the analysis tools used. 
Table 3 Significance value of variable

\begin{tabular}{ccc}
\hline No & Variable & Significance \\
\hline 1 & Precipitation & 0.000 \\
2 & Land-use & 0.001 \\
3 & Groundwater Usage & 0.039
\end{tabular}

Statistical analysis methods used in this study were T-test, ANOVA, and Regression Analysis. Hypothesis testing shows that each variable shows a significant effect with $\alpha<0.05$ with the magnitude of the influence of $95.4 \%$ on the decrease in groundwater level.

\section{CONCLUSIONS}

This study analyzes the effect of rainfall, changes in land use and volume of groundwater use in the Gedebage subdistrict and applies a hydrological and statistical calculation model to simulate the magnitude of groundwater subsidence and investigate future projected trends. This analysis provides several conclusions summarized as follows.

a. The analysis of runoff showed that there was an increment every year from 2014 to 2018 of $21.3 \%$, from $35.69 \mathrm{~m} 3$ $/ \mathrm{sec}$ to $43.29 \mathrm{~m} 3 / \mathrm{sec}$ with an average increment of $4 \%$ per year. b. The analysis of land use changes indicated that there had been a change of land use in the study area, namely in the Gedebage of $20.9 \%$ from 2014 to 2018 with an average change of $4 \%$.

c. Groundwater contour analysis showed that there had been a change in groundwater level elevation which had caused a reduction in groundwater volume from 2014 to 2018 of 101.069.621 Million Cubic.

d. The direct effect of precipitation, landuse changes and amount of groundwater usage variables on groundwater level decreassion was $95.4 \%$.

Considering the magnitude of the influence, it indicates that the possibility of a decline in the future is very large. By using the same method this type of analysis is expected to be made more reliable and used to support decision making, for example in city development strategies and environmental preservation. 


\section{Acknowledgements}

This study was a part of a magister research study in SanggaBuana University, Bandung, Indonesia. I would like to express my special thanks of gratitude to my teacher Dr. Ir. H. Bakhtiar Abu Bakar, MT, (II) Dr. Ir. R. DidinKusdian, MT who gave me the golden opportunity to do this study, which also helped me in doing a lot of Research and I came to know about so many new things I am really thankful to them. Secondly I would also like to thank my parents and friends who helped me a lot in finalizing this project within the limited time frame. Thanks to Gedebage people who gave perception data for statistical analysis. All the observed data were provided by the Department of Energy and minerals resources and Meteorology (BMKG), Bandung and we thanks to them too. Thanks to reviewers for their valuable comments and suggestions on the manuscript.

\section{REFERENCES}

[1] Kodoatie, R. J. (2012). Tata Ruang Air Tanah. Penerbit Andi.
[2] Kodoatie, R. J., \& Sjarief, R. (2010). Tata ruang air. PenerbitAndi.

[3] Suripin (watervoorziening.). (2002). Pelestarian sumber daya tanah dan air. Andi.

[4] Seo,S.B.,Mahinthakumar,G., Sankarasubramanian, A., \& Kumar, M. (2018). Conjunctive management of surface water and groundwater resources under drought conditions using a fully coupled hydrological model. Journal of Water Resources Planning and Management, 144(9), 04018060.

[5] Topaloglu, F., (2002). Determining suitable probability distribution models for flow and precipitation series of the Seyhan river basin. Turkish Journal of Agriculture and Forestry, 26(4), 187-194.

[6] Soewarno, 1995,"Hidrologi Aplikasi Metode Statistik Untuk Analisa Data", Penerbit Nova, Bandung.

[7] Lee, C. (2005). Application of rainfall frequency analysis on studying rainfall distribution characteristics of Chia-Nan plain area in Southern Taiwan. Crop Environ. Bioinf, 2, 31-38.

[8] Wibowo, M. (2019). Model Penetuan Kawasan Resapan Air untuk Perencanaan Tata Ruang Berwawasan Lingkungan. Jurnal Hidrosfir Indonesia, 1(1).

[9] Taylor, J. R., \& Lovell, S. T. (2012). Mapping public and private spaces of urban agriculture in Chicago through the analysis of high-resolution aerial images in Google Earth. Landscape and urban planning, 108(1), 57-70. 